\title{
ATTITUDE TOWARD FOOD IN ASPECT OF RISKS AND BENEFITS RELATED TO THE CONSUMPTION OF EDIBLE INSECTS BY POLISH CONSUMERS
}

\author{
Joanna Bartkowicz ${ }^{1}$
}

${ }^{1}$ Gdansk College of Health, Faculty of Physiotherapy and Health Science, Gdansk, Poland

\begin{abstract}
Background. This study is an introduction to the of learning key factors affecting the process of acceptance of edible insects by Polish consumers, currently only from Gdańsk, Gdynia and Sopot (the Tri-City) in northern Poland.

Objectives. The aim of this study was to assess the attitudes of Tri-City consumers towards edible insects. It was expressed in the assessment of food diversity in relation to eating benefits of edible insects and to assessment of the levels of dietary neophobia for consumers who perceive the risk of eating them. This study contributes to consumers' getting used to edible insects.

Material and methods. The study was carried out in 2015 among 788 participants ranged from 16 to 80 years. The criterion for participation was the place of residence - the Tri-City. The respondents were qualified in three age groups 16-20 years old, 21-40 years old and over 41 years old. The study was conducted using a survey method. The survey questionnaire included the following scales: the Food Neophobia Scale (FNS) and the Variety Seeking Tendency Scale (VARSEEK) perceiving benefits and perception of health hazards associated with the consumption of edible insects compared to traditional and culturally foreign food.

Results. The majority of seekers with a high degree of VARSEEK were men aged 21-40 with higher education. The degree of search for diversity in food significantly depended on factors such as gender, age and education. Gender statistically significantly differentiated the opinions of the respondents regarding the health benefits conditioned by the consumption of various products only in the case of snakes and crickets. A statistically significant effect of age on the opinions of respondents regarding health benefits was shown, which was related to the consumption of: snakes, locusts, horse, tarantula. Whereas it was highly significant when it comes to consumption of: snails, crickets, poultry, beef and pork was demonstrated. Age and education were the factors that had a significant influence of the neophobia level, while gender did not have a significant influence.

Conclusion. Respondents from the Tri-City were characterized by high openness to new food. The 21-40 age group with university education was particularly outstanding. More women than men had low levels of neophobia. At the same time, it was mainly men who were looking for diversity in food. The obtained results try to explain the issue of acceptance conditions of a new and rather controversial product, which are edible insects to the inhabitants of Europe.
\end{abstract}

Key words: edible insects, attitude, food neophobia, variety seeking, Polish consumers

\section{STRESZCZENIE}

Wprowadzenie: Niniejsze badanie jest wstępem do procesu poznawania kluczowych czynników wpływających na proces akceptacji owadów jadalnych przez polskich konsumentów, na chwilę obecną tylko z obszaru miast Gdańska, Gdyni i Sopotu (Trójmiasta) północnej Polski.

Cel: Celem badań była ocena postaw trójmiejskich konsumentów (Polska) wobec owadów jadalnych, wyrażająca się w ocenie stopnia poszukiwania różnorodności w żywności względem korzyści zdrowotnych związanych ze spożycia owadów jadalnych oraz ocenie poziomu neofobii żywnościowa konsumentów dostrzegających ryzyko w ich spożywaniu.

Material i metody: Badanie przeprowadzono wśród 788 osób w wieku od 16 do 80 lat. Kryterium udziału było miejsce zamieszkania - Trójmiasto. Respondentów zakwalifikowano w trzech grupach wiekowych 16-20 lat, 21-40- lat i powyżej 41 roku życia. Badanie zrealizowano za pomocą metody ankietowej. Kwestionariusz ankiety zawierał skale: FNS (Food Neophobia Scale) i VARSEEK (Variety Seeking Tendency Scale) postrzegania korzyści i zagrożeń zdrowotnych związanych ze spożyciem owadów jadalnych w porównaniu do żywności tradycyjnej i obcej kulturowo.

Corresponding author: Joanna Bartkowicz, Gdansk College of Health, Faculty of Physiotherapy and Helath Science, Pelplinska str 7, 80-335 Gdańsk, Poland, e-mail: viobart@op.pl 


\begin{abstract}
Wyniki: Osobami poszukującymi, o wysokim stopniu VARSEEK w większości byli mężczyźni w wieku 21-40 lat z wykształceniem wyższym. Stopień poszukiwania różnorodności w żywności istotnie zależał od czynników takich jak: płeć, wiek i wykształcenie. Płeć różnicowała istotnie statystycznie opinie badanych w kwestii korzyści zdrowotnych uwarunkowanych spożyciem różnych produktów jedynie w przypadku węży i świerszczy. Wykazano istotny statystycznie wpływ wieku na opinie badanych dotyczące korzyści zdrowotnych związanych ze spożyciem: węży, szarańczy, koniny, tarantuli oraz wysoce istotny w przypadku spożycia: ślimaków, świerszczy, drobiu, wołowiny i wieprzowiny. Czynnikami wpływającymi istotnie statystycznie na zróżnicowanie poziomu neofobii były wiek i wykształcenie.

Wnioski: Respondenci z Trójmiasta charakteryzowali się dużą otwartością na nową żywność. Szczególnie wyróżniała się grupa wiekowa 21-40 lat, z wyższym wykształceniem. Więcej kobiet niż mężczyzn charakteryzowało się niskim poziomem neofobii. Jednocześnie to głównie mężczyźni byli poszukującymi różnorodności w żywności. Uzyskane wyniki próbują wyjaśnić kwestię warunków akceptacji nowego i raczej kontrowersyjnego produktu, jakim są jadalne owady dla mieszkańców Europy.
\end{abstract}

Słowa kluczowe: owady jadalne, postawy, neofobia żywnościowa, poszukiwanie różnorodności, polscy konsumenci

\section{INTRODUCTION}

Changing the perception of insects as an alternative food source for consumers in Europe requires time and overcoming many barriers. Disgust, fear, health concerns, panic and anxiety are the emotions that accompany consumers with regard to insects as food. At the same time, one can also observe curiosity and willingness to try new, unique food in Europe. Not only are edible insects a natural and rich source of protein, but they also contain other nutrients such as fats including especially polyunsaturated fatty acids, vitamins, minerals and dietary fiber. Edible insects are known and consumed mainly in the tropical and subtropical climate zone. This phenomenon is termed entomophagy.

Contrary to the belief that insects are eaten only in times of scarcity, people consume edible insects of choice because they are tasty and have their permanent place in the culture of many countries [38]. Currently, for at least 2 billion people in the world edible insects are part of the traditional diet and the highest consumption is recorded in Africa, Asia and Latin America [39].

European research indicates that consumers are very interested in edible insects as food $[5,16,7,20$, $11,4]$. It is difficult convince a Western consumer to eat insects, despite rational arguments regarding environmental protection, nutritional value and safety of this type of food and their excellent taste. Emotional and psychological obstacles make it difficult for consumers to accept insects. There are experiments showing that dietary patterns are constantly changing, as was the case with raw fish in sushi or seafood. The interpenetration of cultures and in this cuisine also means that we reach for fruit, vegetables, alcohol, sweets, cheese, seafood, coffee, tea, meats not from our latitude. Consumers are increasingly choosing food between known and unknown one. The term "known" means both the fact that they have the knowledge and experience associated with it. "Unknown", "new", "novel" foods include foods that they have heard or not heard about. It is likely that they have seen them, but they have no experience with them, and have not tried them.

Traditional food may be new and unknown to people from other cultural backgrounds [13]. Rozin and Fallon, 1987 [33] noted that an unknown object, including culturally different food, may cause fear, aversion and disgust, and that the reason for such reactions is the lack of knowledge and experience related to it as well as individual characteristics, including a high level of neophobia.

Edible insects as food are culturally distant for Europeans, although data confirm their consumption in the world $[1,3,9,26]$. Insects have been consumed by people since the dawn of time [18] and are still being consumed in many parts of the world $[16,19,35]$.

The natural resources of both the flora and fauna of Europe's climate zone have determined food sources. Climate values have determined the cultivation of specific plants (cereals, legumes, and breeding, among others, cattle, sheep, pigs, poultry, as well as the use of forest resources - game and fruit. Religion was and is now an important factor influencing the type of food consumed.

From a consumer's point of view, a product is new if it is considered by a consumer as such. It affects the state of arousal of a consumer, and as the gap between known and unknown increases, the degree of arousal increases as well. In addition to the level of arousal, exploratory activity is affected by the level of felt anxiety. The desire to explore reaches its maximum level with a minimum level of anxiety. Some people are susceptible to anxiety and their propensity to explore is significantly reduced [14].

The choice of a specific product by a consumer is also influenced by the opinion of others, advertising, dedication - less time is spent on buying basic food products. Each consumer has his own hierarchy of preferences. He chooses the product that best meets his requirements [23]. The food that will be accepted is the one people expect, which will be good for their health and taste [32]. 
Indirect information on the taste and/or benefits of novel foods may contribute to a reduction in the level of neophobia and an increased propensity to try them. For example, when others say it is tasty or good for health, people tend to be more likely to try it [30]. However, when food is disgusting, positive information about health benefits and taste is usually not effective [27]. Only direct information obtained through one's own experience can have a positive impact on the level of neophobia. People tend to generalize and positive experiences with new foods reduce their overall level of neophobia [30].

Shiv and Fedorikhin [ 34] put forward a thesis that consumers' behavior in food market significantly shapes consumers' attitudes. They are manifested as the tendencies to permanent or stereotypical ways and forms of responding to a given stimulus in a specific situation. In relation to unknown food, one should expect relatively frequent occurrence of ambivalent attitudes, containing both positive and negative components. Ambivalence may manifest itself when there is a conflict between curiosity and fear of consequences of the consumption, between appearance and knowledge of the nutritional value of a product, and ,thus, the conflict of seeking and avoiding.

The research of the phenomenon of neophobia in relation to food has been carried out in many countries, regardless of whether we are dealing with culture of the East or the West. The increasing availability of multicultural food also results in the interpenetration of dietary habits and their constant change, and this makes research on attitudes toward food timely and relevant in the context of continuous and dynamic cultural change.
Overcoming the reluctance of the most potential consumers to accept a new product - a novel food such as edible insects - also requires a change in dietary habits and encouragement to transform existing dietary patterns. The social dimension of such an action will be the development of steps to introduce edible insects, a product with high health value as a food attractive to consumers on the European market. In view of the observed activities promoting the consumption of insects in Europe, it may turn out that consumers from the Tri-City area will constitute an appropriate target group of these activities.

The aim of this study was to assess the degree of search for diversity in food in relation to the health benefits associated with the consumption of edible insects and to assess the level of food neophobia of consumers perceiving the risk in their consumption.

\section{MATERIAL AND METHODS}

\section{Research material}

The study was carried out in 2015 among 788 participants from Gdańsk, Gdynia and Sopot, (TriCity) in northern Poland, with age ranging between 16 and 80 years. The selection criteria of the sample took Tri-City into account as the place of residence. The respondents were classified into three age groups: 16-20 years old, 21-40 years old, over 41 years old. The detailed profile of respondents was presented in Table 1.

Table 1. Sample of sociodemographic characteristics

\begin{tabular}{|c|c|c|c|c|c|c|c|}
\hline \multicolumn{2}{|c|}{ Gender } & \multicolumn{3}{c|}{ Age } & \multicolumn{3}{c|}{ Education } \\
\hline Female & Male & $16-20$ years & $21-40$ years & over 41 years & Professional & Secondary & Higher \\
\hline 592 & 196 & 284 & 293 & 211 & 94 & 425 & 269 \\
\hline
\end{tabular}

\section{Methods}

The questionnaires included the scale of looking for diversity in food called Variety Seeking Tendency Scale (VARSEEK) [40], the scale of neophobia in relation to food - Food Neophobia Scale (FNS) [29] and also the assessment of risk and benefits of insects' consumption. The items were rated on a five-point Likert scale with all categories labeled, ranging from completely disagree $(=1)$ to completely agree $(=5)$. Items 6, 7 in VARSEEK scale (Table 2) and items 2, 3, 5,7 and 8 in FNS scale (Table 5) were recoded before analysis. Thus, on the FNS scale, the higher the total individual score, the lower the level of food neophobia.

The degree of perception of health benefits was also estimated [ 6 degrees scale: no health benefits
$(=1)$ - high health benefits $(=6)]$ and the degree of perception of health risk [ 6 degrees scale: no risk $(=1)$ - high risk (=6)] associated with the consumption of edible insects compared to familiar (traditional) and unfamiliar (culturally different foods).

\section{Statistical analysis}

The results were analyzed statistically using the analysis of variance, reliability of Cronbach 'Alpha, Rho Spearman, $R$ Pearson against other scales and variable benefits and risks of eating edible insects. The MannWhitney $\mathrm{U}$ test was used. A correction for normality was applied and the Kruskal-Willis test was used. 
To investigate the relationship between variables, the $\chi^{2}$ test of independence was used. Statistica 12.0 software (StatSoft Corp., Kraków, Poland) was used to determine statistically significant differences at a significant level of $p$-value $\leq 0.05$.

\section{RESULTS AND DISCUSSION}

\section{Levels of Variety Seeking Tendency}

The scale used to determine the level of search for diversity in food was that of VARSEEK. For analysis, the subjects were divided into three subsamples consumer high, medium and low in a variety of seeking tendency - on the basis of the 33 and 67 percentiles of the distribution of the VARSEEK scores. Scale reliability was also calculated based on Cronbach's Alpha. The results are included in the table (Table 2).

Consumers for whom the scale value was 26 and below were classified as people with a low tendency to seek diversity in food, described in the literature as avoiders. Scale values of 32 and higher characterized consumers with a high tendency to search, called seekers. The range of values between 27 and 31 was specific for people with a medium search tendency (Figure 1).

Table 2. Variety Seeking Tendency Scale (VARSEEK)

\begin{tabular}{|c|l|c|}
\hline No & \multicolumn{1}{|c|}{ Statement } & \\
\hline 1. & When I eat out, I like to try the most unusual dishes, even if I am not sure I would like them & \\
\hline 2. & While preparing food or snacks, I like to try out new recipes & \\
\hline 3. & I think it is fun to try new food items one is not familiar with & \\
\hline 4. & I like to eat exotic food & \\
\hline 5. & I am eager to know what kind of food people from other countries eat & \\
\hline 6. & Dishes on the menu that I am unfamiliar with make me anxious (R=recoded) & \\
\hline 7. & I prefer to eat food products I am used to (R) (N) & \\
\hline 8. & I am curious about food products I am not familiar with & 0,794 \\
\hline & Cronbach's Alpha & 26 \\
\hline & First quartile & 32 \\
\hline & Third quartile & \\
\hline
\end{tabular}

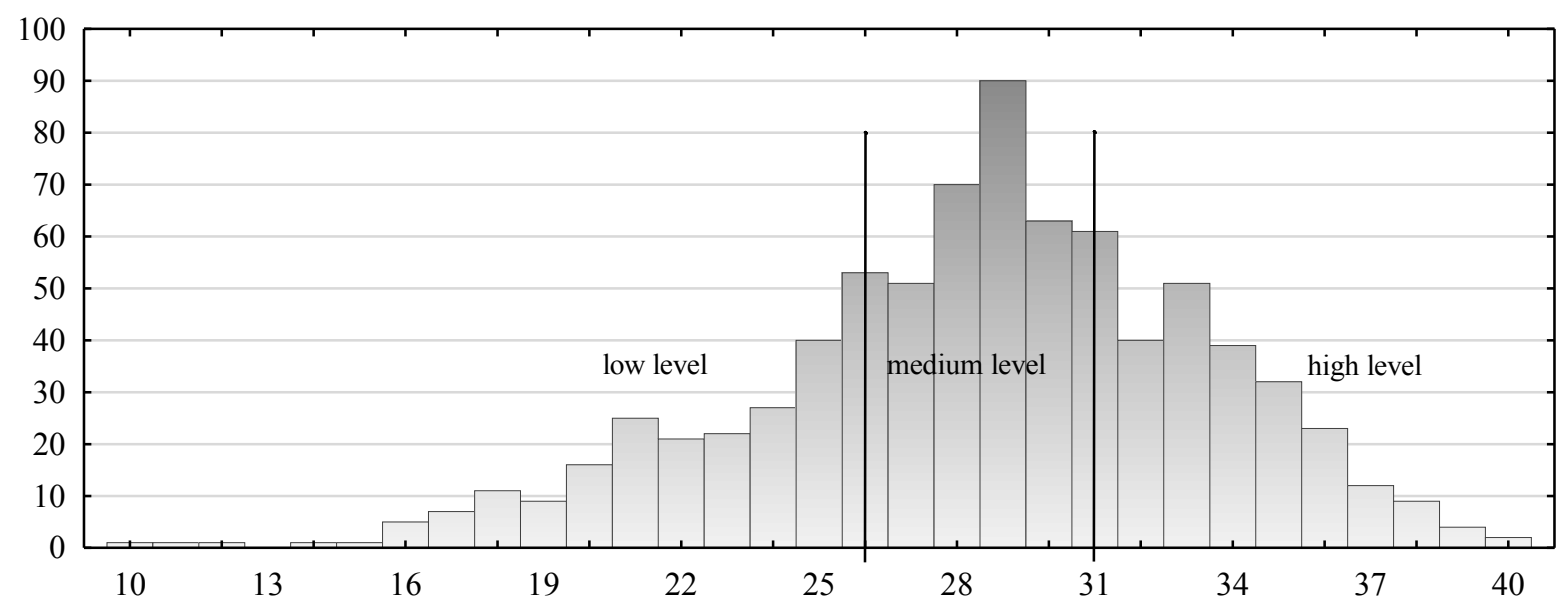

Figure 1. Variety Seeking Scale (VARSEEK) results for population

The majority of respondents $(42.51 \%)$ including 246 women and 71 men represented the average level of search for diversity in food. The low and high level of search for diversity in food was represented by a similar percentage of respondents $(30.58 \%$ and $26.90 \%$ ), with 183 women and 58 men representing the low level. The seekers group was dominated by men with a $10 \%$ advantage over women. Characteristics of the studied population, such as: gender $\left(\chi^{2}=7.6501\right.$ at $\mathrm{p}=0.022)$, age $\left(\chi^{2}=11.6512\right.$ at $\left.\mathrm{p}=0.020\right)$ and education $\left(\chi^{2}=13.3205\right.$ at $\left.\mathrm{p}=0.010\right)$ showed a statistically significant relationship with the estimated level of searching for diversity in food. 
Differences in the search for diversity in VARSEEK based on gender were observed within medium and high levels (Table 3). In the case of low levels of diversity search, the percentage of women and men was similar, $30.92 \%$ and $29.56 \%$ respectively. Men with a high level of VARSEEK search were more likely to explore food compared to women, with a nearly $10 \%$ higher percentage $(9.7 \%)$. Within the average level, the share of women $(44.56 \%)$ was higher than that of men $(36.22 \%)$.

Table 3. Attitude of participants according to Variety Seeking Scale (VARSEEK) in terms of gender, age and education (\%)

\begin{tabular}{|c|c|c|c|c|c|c|c|c|c|}
\hline \multirow{2}{*}{$\begin{array}{c}\text { Level of } \\
\text { VARSEEK }\end{array}$} & \multicolumn{2}{|c|}{ Gender } & \multicolumn{3}{|c|}{ Age [years] } & \multicolumn{3}{c|}{ Education } & \multirow{3}{*}{ Total } \\
\cline { 2 - 10 } & \multicolumn{2}{|c|}{$\mathrm{p}=0.022^{*}$} & \multicolumn{3}{|c|}{$\mathrm{p}=0.020^{*}$} & \multicolumn{3}{c|}{$\mathrm{p}=0.010^{*}$} & \\
\cline { 2 - 11 } & Female & Male & $16-20$ & $21-40$ & over $\geq 41$ & Vocational & Secondary & Higher & \\
\hline Low & 30.92 & 29.59 & 31.34 & 24.91 & 37.44 & 43.61 & 31.53 & 24.54 & 30.58 \\
\hline Medium & 44.59 & 36.22 & 44.72 & 43.34 & 38.39 & 35.11 & 43.06 & 44.24 & 42.51 \\
\hline High & 24.49 & 34.19 & 23.94 & 31.75 & 24.17 & 21.28 & 25.41 & 31.22 & 26.90 \\
\hline
\end{tabular}

*statistically significant differences at $\mathrm{p}<0.05$

The group characterized by a high level of searching for diversity in food was represented by people aged $21-40$ years $(31.75 \%)$. However, people belonging to the other two age groups constituted a similar percentage of the surveyed population: $23.94 \%(16-$ 21 years old) and $24.17 \%$ (over 41 years old). Despite the distribution of obtained results, the highest values could be expected among the youngest people aged 1620 . Young people entering the adult life usually show behaviors conducive to learning about it. A probable reason for the distribution of results may be the financial issue and the related lack of independence in running households by young people and dependence on parents. In the group characterized by a low level of searching for diversity in food, people over 41 years of age $(37.44 \%)$ and $18-20$ years of age $(31.34 \%)$ dominated. On the other hand, the average level of searching for diversity in food dominated in all age groups.

While analyzing the impact of education level, it was observed that in the group of people with a low level of search $(30.58 \%$ of the respondents in total) the least numerous group comprised of respondents with higher education, whose share was $24.54 \%$. On the other hand, the highest percentage showed people with vocational education (43.61\%), while the average percentage was $31.53 \%$. The average level of diversity search in the highest percentage was represented by people with higher education (44.24\%) and secondary education $(43.06 \%)$. Respondents with vocational education had the lowest share (35.11\%). Respondents with higher education presented the highest percentage of all categories of education, willingness to search for diversity $(31.22 \%)$. In turn, the group with vocational education had the lowest percentage $(21.28 \%)$ of people willing to seek diversity in food. The group of people with higher education levels showed a greater willingness to explore food than the group with vocational education levels. The observed phenomenon may be connected with a higher income of people with higher education level, which in consequence may provide greater opportunities to travel and learn about local specialties or new restaurants serving national cuisines of other countries.

Similar studies were conducted by Januszewska et al. [12]. In these studies, higher education also turned out to be a factor distinguishing a group of Belgians looking for diversity in food. This group was characterized by an average income and their place of residence was a village. These results indicate that there is a certain similarity in the attitudes of Belgians regarding the search for diversity in food and neophobia with respect to food from the Tri-City respondents, although the study conducted among the Tri-City residents did not include income as a factor differentiating the studied population. The cited study concerned the assessment of attitudes to the search for diversity in food and neophobia toward food among the inhabitants of the region of Małopolska (Poland) and East Flanders (Belgium). It was found that the Polish group looking for diversity in food (high level of VARSEEK) was represented by people with lower income, and the price of new products was a very important factor for them. Although these people were characterized by lower income levels, they were ready to spend larger amounts on the purchase of more expensive products.

A study by Dodd et al. [8] on the search for diversity in wines showed that those seeking high diversity confessed to trying unusual kinds of this alcohol, even if they were not sure whether they would like them or not. Respondents tried exotic wines from different parts of the world, in line with Kish and Donnenworths' [15] thesis that people who seek new experiences have a stronger than average need for action. In the Dodd et al. [8] study no significant correlation was found between age, income, consumer education and the degree of seeking diversity in food. 
Seekers of high diversity spent more money on wine and consumed more wine than those who avoided diversity. However, no significant influence of income and education of the respondents on differentiation of diversity search level was found.

By comparing the distribution of search levels obtained in the study by Olsen et al. [25] with the results for Tri-City consumers, it can be stated that it differs particularly in terms of a low level of diversity, that is, by as much as $14.62 \%$ (15.96\% of the USA vs. $30.58 \%$ of Polish consumers - from Tri-City). As far as the high level of searching for diversity is concerned, the opposite relationship was observed. The percentage of Tri-City consumers with a high search level was $12.75 \%$ lower than those surveyed in the USA ( 26.90 vs. $39.65 \%)$. The percentage of people with a medium level of searching was similar in both groups, with a difference of $1.88 \%(44.39 \%$ the USA vs. $42.51 \%$ Polish consumers). It can be assumed that the identified differences result from different economic conditions in both countries.

\section{Health benefits of consuming familiar and unfamiliar products}

Opinion data on the health benefits of eating selected products of animal origin (frog legs, sea food, snails, snakes, locusts, crickets, horse meat, tarantula, poultry, pork, beef and venison) were analyzed. This group includes both native and unknown products, as well as culturally unfamiliar products. The original empirical data, being the respondents' answers to the scale questions, were analyzed in clusters. In these scales, the items were traditional (conventional) and non-traditional (unconventional) products. The criterion of cluster searching focused on health benefits resulting from consumption of traditional and non-traditional products. The conducted analysis showed that the scale-of-benefits item was divided into two clusters (Figure 2).

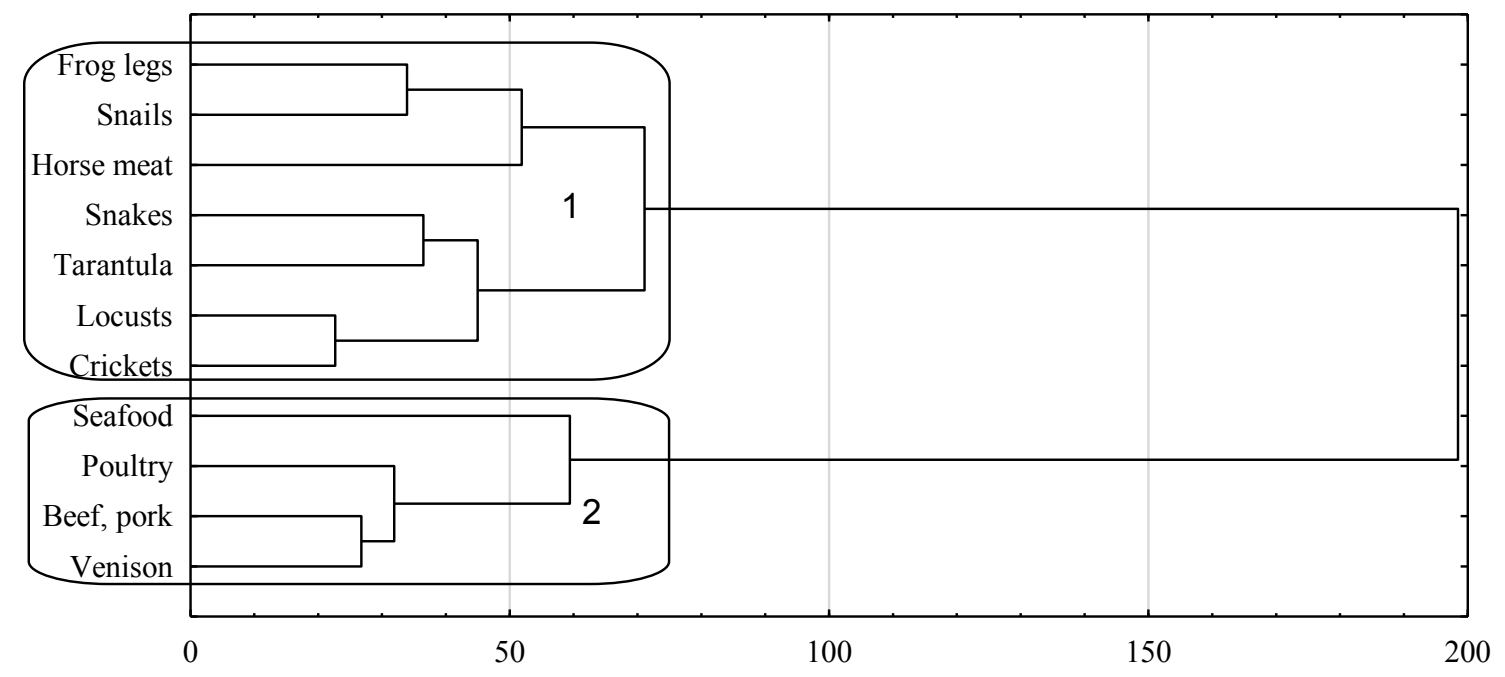

Figure 2. Clustering health benefits of consuming traditional and non-traditional products (Ward's method, Euclidean bond)

Cluster 1 included products such as: poultry, beef, pork, game and seafood, which should be treated as known products with which consumers are already "familiar". Seafood was added to such objects as game, beef, pork and poultry in the last knot of this concentration, as a product more different from them. The degree to which these products were linked with each other was the greatest, and so they found themselves in one cluster. These products were combined (aggregated) into one cluster 1, which differs from the other aggregated products in cluster 2 .

Cluster 2 included products such as: frogs' legs, snails, snakes, locusts, crickets and horsemeat that could be described as products other than those normally consumed.

Based on the results of cluster analysis, concerning the study of health benefits associated with the consumption of a specific group of traditional and non-traditional products, it can be concluded that seafood is well established in the awareness and menu of the surveyed consumers. Venison, which has been a traditional dish in Polish cuisine dating back to hundreds of years, although it is not a product as widely used in nutrition as poultry or pork and beef, is still perceived as a product with beneficial health values associated with its consumption. However, horse meat, although also known and served in Poland as food, was perceived similarly to other atypical products by a native consumer. Although Poland is the undisputed leader in horse meat production (the second one in the European Union; export value of 21 million $€$ in 2012), horse meat consumption in Poland remains low [28].

The data show a clear tendency regarding the perception of large and rather large health benefits associated with culturally known products such as poultry $(62.3 \%)$, beef, pork $(61.2 \%)$ and venison $(60.9 \%)$. This group also includes seafood $(56.6 \%)$ 
perceived similarly to venison ( $4.3 \%$ difference). Such a large percentage of indications related to the perception of health benefits resulting from the consumption of seafood may indicate how well they have been accepted on the Polish market and how their perception by Poles has changed. Horse meat (25.4\%), known and served in Poland for longer than seafood, was found to be less beneficial for health, which was reflected in more than half of the lower percentage of indications compared to seafood. Tarantulas and snakes were ranked by respondents in terms of benefits at the end of the list of products $(6.5 \%$ and $6.2 \%$ of indications respectively). It is worth noting that in the case of consuming products such as crickets $(15.6 \%)$ and locusts $(12.9 \%)$ health benefits were noticed, although they are not known or common on the Polish market. At the same time it should be emphasized that among the respondents there were people who did not perceive health benefits resulting from consumption of such products commonly found on the Polish market as, for example, poultry (3.5\%) or beef and pork $(4.1 \%)$. Also in the case of eating venison, $4.3 \%$ of respondents did not see any benefits. In the case of seafood, only $6.6 \%$ of respondents stated that there were no health benefits resulting from including them in their diet.

Gender slightly differentiated the opinions of the respondents on the issue of health benefits caused by the consumption of various products - significant differences $(p \leq 0.05)$ were found only in the case of: snakes and crickets. However, a significant (level of significance $p \leq 0.05$ ) influence of age on the opinions of the respondents (concerning health benefits) related to the consumption of: snakes, locusts, horsemeat, tarantula and highly significant (level of significance $\mathrm{p} \leq 0.001)$ when it comes to the consumption of: snails, crickets, poultry, beef and pork.

\section{VARSEEK levels and health benefits of familiar and unfamiliar products}

The relationship between the level of search for diversity in food and health benefits of food consumption has been assessed. For this assessment, Rho Spearman's rank correlations were used, demonstrating a number of important relationships between the studied variables (Table 4).

Table 4. Spearman's correlation between the Variety Seeking Scale (VARSSEK) level and the assessment of health benefits associated with the consumption of selected products

\begin{tabular}{|c|c|c|c|c|c|c|c|c|c|c|c|}
\hline \multirow[b]{2}{*}{ Correlation } & \multicolumn{11}{|c|}{ Health benefits } \\
\hline & $\begin{array}{l}\infty \\
\frac{\infty}{0} \\
000 \\
00 \\
0\end{array}$ & $\begin{array}{l}\overrightarrow{8} \\
8 \\
0 \\
\mathscr{E} \\
\mathscr{B}\end{array}$ & $\begin{array}{l}\stackrel{0}{\vec{E}} \\
\text { क }\end{array}$ & $\frac{\mathscr{d}}{\tilde{a}}$ & $\begin{array}{l}0 \\
0 \\
0 \\
0 \\
0 \\
.\end{array}$ & 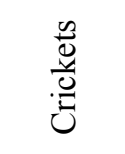 & 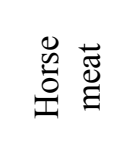 & 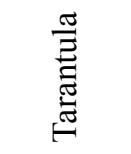 & 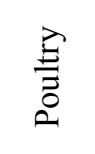 & $\begin{array}{l}4 \\
0 \\
0 \\
\dot{1} \\
0 \\
0\end{array}$ & 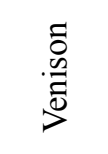 \\
\hline $\begin{array}{c}\text { Rho } \\
\text { Spearman } \\
\text { VARSEEK }\end{array}$ & $0.179 * *$ & $0.245 * *$ & $0.188 * *$ & $0.207 * *$ & $0.190 * *$ & $0.232 * *$ & $0.155^{* *}$ & $0.161 * *$ & 0.035 & 0.022 & $0.111^{*}$ \\
\hline
\end{tabular}

*Statistically significant differences at $\mathrm{p}<0.05 ; * *$ Statistically significant differences $\mathrm{p}<0.001$

Analyzing the relationship between the level of diversity search in food and health benefits resulting from the consumption of edible insects (locusts and crickets), a statistically significant relationship (at the level of significance $\mathrm{p} \leq 0.001$ ), with positive values of 0.190 and 0.232 respectively, was found, which means that this relationship cannot be considered as strong [36]. While comparing the culturally foreign products listed in Table 4, such as frog legs, seafood, snails, snakes and tarantulas, the highest correlation value added another crucial information to this study. Generally, its role is to indicate the existence of a relationship between the attitude to food seeking food diversity and the perception of health benefits resulting from consumption of various types of products. As it turned out, the highest correlation value was recorded for seafood (Spearman coefficient - 0.245) and the lowest for tarantula (0.161).
The studied relationships were characterized by a statistically significant but weak strength of this relationship. Based on the comparison of the Rho Spearman correlation values between VARSEEK and the assessment of health benefits associated with the consumption of specific products, it can be assumed that respondents with a higher level of seeking diversity were at the same time willing to see higher health benefits associated with the consumption of unusual products, including culturally unfamiliar ones. No statistically significant relationships between variables were found when analyzing the examples of poultry $(0.035)$, pork and beef (0.022). A surprising result is the finding of low correlation values between the studied phenomena in the case of game $(0.111)$ and horse meat $(0.155)$, which were comparable to the values determined in the case of frog legs (0.179) or snails (0.188). Wild game has been a traditional dish in Polish cuisine dating back 
to hundreds of years. Currently, the consumption of game meat in Poland is marginal and $90 \%$ of Polish production is exported to Germany, France, Italy and the Benelux countries. The production volume is estimated at 7-8 thousand tons of chilled and frozen meat [28]. Also, the consumption of horse meat in Poland is very low and not very popular in comparison with countries such as Italy or France, despite the fact that Poland is one of the largest exporters of horse meat in Europe. The reasons for this state of affairs can be seen in the history of Poland and Poles' great attachment to horses which increasingly often are associated with studs instead of farming and perceived as a friend of man, just like dogs.

The results of the study may suggest that consumers with strongly polarized views on the search for diversity in food do not pay attention to the nutritional value of traditional products (poultry, pork and beef) and at the same time do not notice the risk associated with their consumption. Both seekers and those who avoid diversity in food perceive the values of traditional products such as poultry, pork and beef in a similar way. Traditional products, as basic sources of protein, commonly used in households in Poland, are considered as basic goods by the respondents, which results from their availability on the market. Over the last fifteen years, meat consumption in Poland has increased by approximately $9 \%$. Pork is still the most commonly consumed type of meat (41 kg per capita in Poland in 2016), followed by poultry (29.5 $\mathrm{kg}$ per capita) and beef $(1.9 \mathrm{~kg})$. In recent years, the structure of meat consumption in Poland has been changing in favor of white meat. The observed growing consumption of poultry meat is consistent with the trends observed in the western countries of the European Union and the USA and is conditioned by a low price of poultry in relation to other types of meat. At the same time, higher consumption of poultry is facilitated by the growing popularity of a healthy lifestyle and the related increased demand for white meat [6]

\section{Levels of Food Neophobia Scale (FNS)}

The FNS scale was used to determine the level of neophobia in new food. The scale is based on 10 statements (five neophilic and five neophobic statements) (Table 5). Individual total scores were obtained by summing the values of each scale item, corresponding to the values $1-5$ and totaling $10-50$ points. A higher number of points corresponds to the neophilic attitude. The mean value of sum $(\bar{x})$ and standard deviation (SD) were calculated and on this basis three groups of respondents were separated. The first group with values 28.98 and lower $(\overline{\mathrm{x}}-\mathrm{SD}$; 34.54-5.56) are people with high levels of neophobia. We describe them in literature as neophobics. The range between 28.98 and 40.10 defined attitudes as neutral (medium) on the level of neophobia. The third group with a low level of neophobia had FNS values above $40.10(\overline{\mathrm{x}}+\mathrm{SD} ; 34.54+5.56)$. These people had a neophlic attitude to new food. The reliability of the FNS scale (Alpha Cronbach's), consisting of 10 items, was estimated at 0.705 .

Table 5. Mean, SD of Food Neophobia Scale (FNS), N=788

\begin{tabular}{|c|l|}
\hline No & \multicolumn{1}{|c|}{ Statement } \\
\hline 1. & I am constantly sampling new and different foods \\
\hline 2. & I don't trust new foods $(\mathrm{R})$ \\
\hline 3. & If I don't know what a kind of food is, I won't try it $(\mathrm{R})$ \\
\hline 4. & I like food from different cultures \\
\hline 5. & Ethnic food looks too weird to eat $(\mathrm{R})$ \\
\hline 6. & At dinner parties and trips abroad, I try new food \\
\hline 7. & I am afraid to eat things I have never had before $(\mathrm{R})$ \\
\hline 8. & I am very particular about the food I eat (R) \\
\hline 9. & I will eat almost anything \\
\hline 10. & I like to try new ethnic restaurants \\
\hline
\end{tabular}

The dominant attitude toward novel food among the respondents was neutral (63.45\%), for which the total response values to FNS statements were between 28.98 and 40.10. Strong attitudes of avoiding and wanting to learn about new products were declared by a similar percentage of respondents, represented by $18.15 \%$ of neophobics and $18.40 \%$ of neophilics, although these groups differed in terms of the participation of women and men. Among people with neophobic attitudes there were nearly $4 \%$ more men than women $(17.23 \%)$. However, among people with low neophobic attitudes (neophilics) there were $6.15 \%$ more women than men $(13.78 \%)$. A similar percentage of women and men were characterized by a medium level of neophobia $(62.84 \%$ and $65.31 \%)$. Among the respondents with a willingness to try new food, the 21-40 age group was characterized by the highest, almost doubled, percentage of people with a low level of neophobia $(25.60 \%)$ compared to the remaining groups $(15.15 \%$ of $16-20$ year-olds and $12.80 \%$ of people over 41 years of age). At the same time, this group had the lowest percentage of people with a high level of neophobia (13.99\%) also compared to other age groups with a similar percentage. In comparison with all age groups, the group of the 2140 years old stood out the most in terms of the level of neophobia, constituting the lowest percentage among the respondents. Socio-demographic factors that had a statistically significant effect on the differentiation in the level of neophobia were age $\left(\chi^{2}=18.75778\right.$; $\mathrm{p}=0.001)$ and education $\left(\chi^{2}=12.45512 ; \mathrm{p}=0.014\right)$, while gender did not have a significant impact differentiating the respondent group in terms of neophobia. The characteristics of the study group, including gender, age and level of education, are presented in Table 6 . 
Table 6. Level of neophobia with regard to gender, age and education (\%)

\begin{tabular}{|c|c|c|c|c|c|c|c|c|c|}
\hline \multirow{2}{*}{$\begin{array}{c}\text { Level } \\
\text { FNS }\end{array}$} & \multicolumn{2}{|c|}{ Gender } & \multicolumn{3}{|c|}{ Age [years] } & \multicolumn{3}{c|}{ Education } & \multirow{3}{*}{ Total } \\
\cline { 2 - 10 } & \multicolumn{2}{|c|}{$\mathrm{p}=0.118$} & \multicolumn{3}{|c|}{$\mathrm{p}=0.001^{* *}$} & \multicolumn{3}{c|}{$\mathrm{p}=0.014^{*}$} & \\
\cline { 2 - 11 } & Female & Male & $18-20$ & $21-40$ & over $\geq 41$ & Vocational & Secondary & Higher & \\
\hline Low & 19.93 & 13.78 & 15.15 & 25.60 & 12.80 & 12.77 & 18.82 & 19.70 & 18.40 \\
\hline Medium & 62.84 & 65.31 & 64.08 & 60.41 & 66.82 & 56.38 & 65.18 & 63.20 & 63.45 \\
\hline High & 17.23 & 20.91 & 20.77 & 13.99 & 20.38 & 30.85 & 16.00 & 17.10 & 18.15 \\
\hline
\end{tabular}

* statistical differences $\mathrm{p} \leq 0.05 ; * *$ statistical differences $\mathrm{p} \leq 0.001$.

Januszewska et al. [12] when surveying two groups of consumers, from Poland (Wielkopolska region) and Belgium(Flanders region), obtained a similar percentage of people with a high level of neophobia toward food (Wielkopolska $19.0 \%$ to Tri-City $18.4 \%$ ), which may indicate a similar attitude of respondents from Tri-City to respondents from the region of Wielkopolska toward food. Among the respondents from Flanders (Belgium) as much as $28.0 \%$ were characterized by a high level of neophobia toward food.

Finnish researchers who analyzed the determinants of neophobic attitudes toward food showed that men were characterized by higher neophobia than women. A representative sample of Finns $(n=1083)$ evaluated the knowledge of 20 dishes classified as "known" or "unknown" and expressed their willingness to try them. Men were more neophobic than women and the elderly (66-80 years old) were more neophobic than other age groups. People with a high level of neophobia toward food were less likely to consume "unknown" dishes than people with a low level of neophobia toward food. These studies also identified factors related to interest in new food and aversion to try unknown products. According to Finnish researchers, neophobia decreases with increasing levels of education and urbanization of the place of residence [37].

A survey of the level and determinants of neophobia toward food among Polish consumers conducted by Kowalczuk [17] allowed for a segmentation of respondents in terms of their neophobia toward food. People with a high level of neophobia accounted for $15.4 \%$, an average of $70.6 \%$ and a low level of neophobia toward food for $13.2 \%$. It was found that gender did not differentiate between the mean value of neophobia and belonging to particular levels of neophobia. Education, income and self-esteem were factors that significantly differentiated neophobia levels. Education as a potential factor differentiating the level of neophobia in relation to food in the study of attitudes conducted among TriCity respondents also proved to be significant.

A study of students from Midwestern University in Downers Grove (Illinois - the USA) measured their level of neophobia in the perception of Chinese and Thai cuisine in the context of attitudes toward food. Analysis of the results obtained using the FNS scale showed that there were no significant differences taking into account factors such as age, gender and place of origin. Respondents who declared that they did not try dishes typical of Chinese or Thai cuisine showed significantly higher average levels of neophobia toward food than those who declared previous experience with these national cuisines [2].

Another example of research on the level of food neophobia was a study conducted among American and Lebanese college students $(n=1122)$ and concerned the impact of variables such as the country of residence and socioeconomic status on the level of food neophobia. The impact of the level of neophobia on knowledge and willingness to taste known and new food products was also examined. Students characterized by food neophilia showed a greater knowledge of products and a desire to try known and new food. The percentage of people in the neophilic group was significantly higher in the United States of America compared to Lebanon (29.4\% vs. $7.9 \%$ ). FNS ratings correlated negatively with the desire to try all food products. Moreover, knowledge and willingness to try them were higher in case of people with low levels of neophobia compared to other neophobia levels for both known and novel food groups. In addition, the desire to try them was almost always higher regardless of the specific level of neophobia for people who have ever tasted food unknown to them compared to those who have never had such an experience [24].

A study of the level of neophobia toward food among Spanish consumers ( $\mathrm{N}=309)$ from Barcelona, Madrid and Valencia showed that gender was not a differentiating factor while age was a statistically significant factor $(p<0.003)$ for differentiating neophobic attitudes toward food. The 25-36 age group showed significantly lower levels of neophobia compared to the 49-60 age group and above 60 years of age. The relationship between food neophobia and readiness to try two unknown kinds of food (aloe drink and sweet sesame rice) was confirmed $(p<0.05)[10]$. 
The research results discussed so far have focused on the western cultural circle, therefore, it is interesting to compare them with the results of studies conducted by Muhammad et al. among students of Klang Valley University (Malaysia). The group of respondents was not homogeneous due to their origin, as the subjects came from Malaysia, China and India. Demographic data made it possible to assess the relationship between the level of neophobia in food and many of the variables characterizing this group. Age (22-25 years old), gender, race, status, occupancy, education and monthly income significantly differentiated neophobia from food. Malaysian students were more neophobic than Indian and Chinese students. Students from rural areas and small towns were more neophobic than students from larger cities [21].

Interesting results were obtained by Muhammad et al. in a study conducted among 300 young people (aged 18-20) aspiring to the profession of chef at three universities in Malaysia. Their level of neophobia toward food was examined using the FNS scale. Contrary to the expectations of a low level of neophobia among students toward new products and dishes due to the field of study, the results turned out to be surprising. Most of the respondents were characterized by low and medium levels of food-related neophobia, but there were also a small number of young chefs with a high degree of food-related neophobia. It was found that neophobia even occurred among people who have had and will be in contact with a variety of foods due to their profession [22].

\section{Health risk of familiar and unfamiliar products}

Cluster analysis that uses the Ward method was also applied to assess the health risk associated with the consumption of the same products for which the assessment of health benefits connected with their consumption was carried out based on the respondents' opinion. Similarly to the results of the assessment of health benefits in this case, two clusters were also obtained (Figure 3).

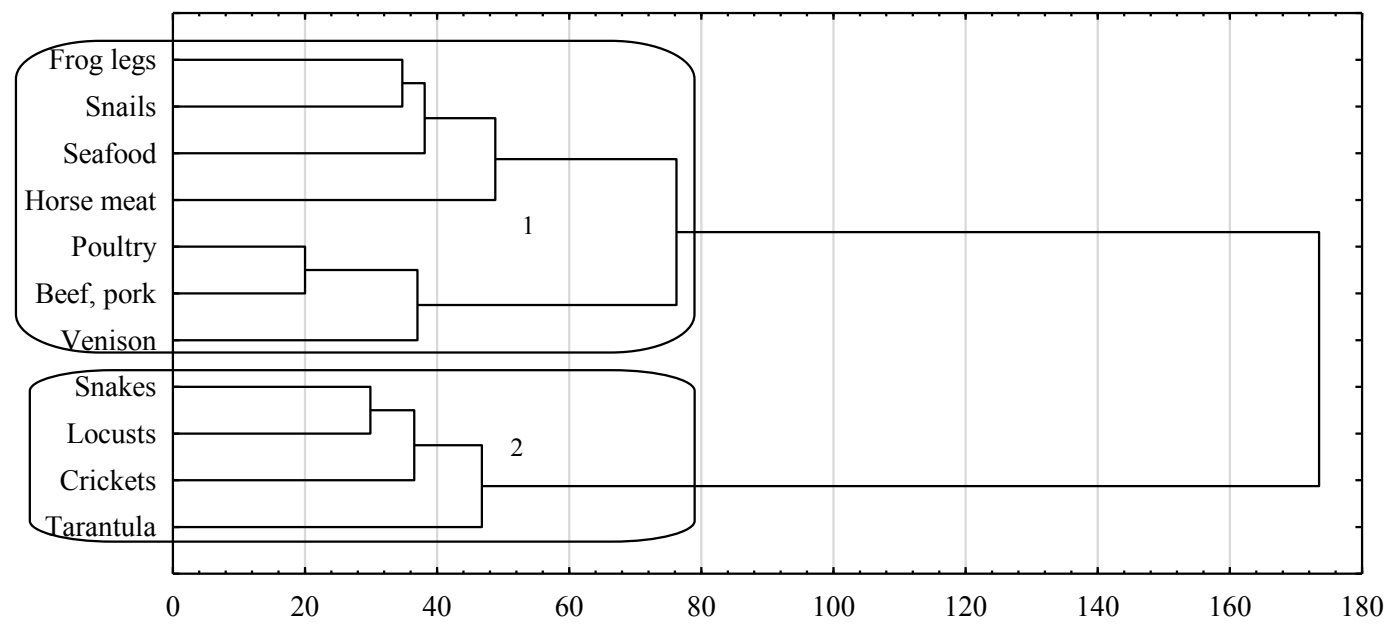

Figure 3. Clustering the assessment of health risks resulting from the consumption of familiar and unfamiliar products (Ward's method, Euclidean bond)

Cluster 1 included products that were unfamiliar (culturally alien) to Polish consumers, such as snakes, locusts, crickets and tarantulas. The second cluster (2) included two subgroups. One of them covered products known and commonly consumed by consumers, such as beef, pork, poultry and game. The second subgroup of concentration 2 included frog legs, snails, seafood and horse meat. The likely reason for this division in the risk assessment and the separation of the second subgroup in cluster 2 is that these products have been known for a long or very long time, although rather rarely consumed. However, consumers are clearly "familiar" with them.

\section{FNS levels and health risks of familiar and unfamiliar products}

The Rho Spearman correlation between the parameters of the Food Neophobia Scale and the risk assessment of consumption of traditional and non-typical products based on the opinion of respondents was also assessed and evaluated (Table 7). Rho Spearman's values indicate that the relationships studied should be assessed as very weak. Only for horsemeat is there a statistical relationship between the perception of risk associated with the consumption and the level of neophobia of the respondents. It was found that the perception of high risk associated with the consumption of horsemeat is accompanied by a high degree of neophobia. In other cases, the significance of correlation was not found. For products such as edible insects (crickets and locusts), the Rho Spearman index ranged from 0.032 to 0.042 with no significance. It was found that the correlation between the degree of food neophobia and the risk assessment resulting from the consumption of edible insects (locusts and crickets) by Tri-City consumers did not occur. 
Table 7. Spearman's FNS rank correlations and risk assessment of selected products

\begin{tabular}{|c|c|c|c|c|c|c|c|c|c|c|c|}
\hline \multirow[b]{2}{*}{ Correlation } & \multicolumn{11}{|c|}{ Health risk } \\
\hline & 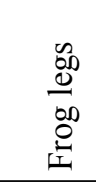 & $\begin{array}{l}\text { D } \\
\stackrel{0}{0} \\
\mathbb{J} \\
\tilde{n}\end{array}$ & 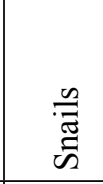 & $\begin{array}{l}\text { Uू } \\
\text { 气ै } \\
\tilde{\Xi}\end{array}$ & $\begin{array}{l}0 \\
0 \\
0 \\
0 \\
0 \\
. \\
\end{array}$ & 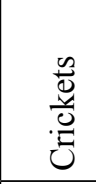 & 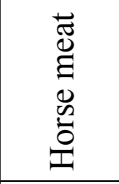 & 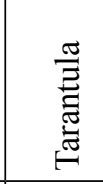 & $\frac{\vec{E}}{\vec{\Xi}}$ & 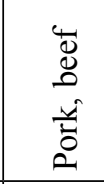 & $\begin{array}{l}0 \\
0 \\
0 \\
00 \\
0\end{array}$ \\
\hline Rho Spearman FNS & 0.053 & 0.027 & 0.067 & 0.018 & 0.042 & 0.032 & $0.080^{*}$ & 0.024 & 0.033 & 0.049 & 0.028 \\
\hline
\end{tabular}

* statistical differences $\mathrm{p} \leq 0.05$

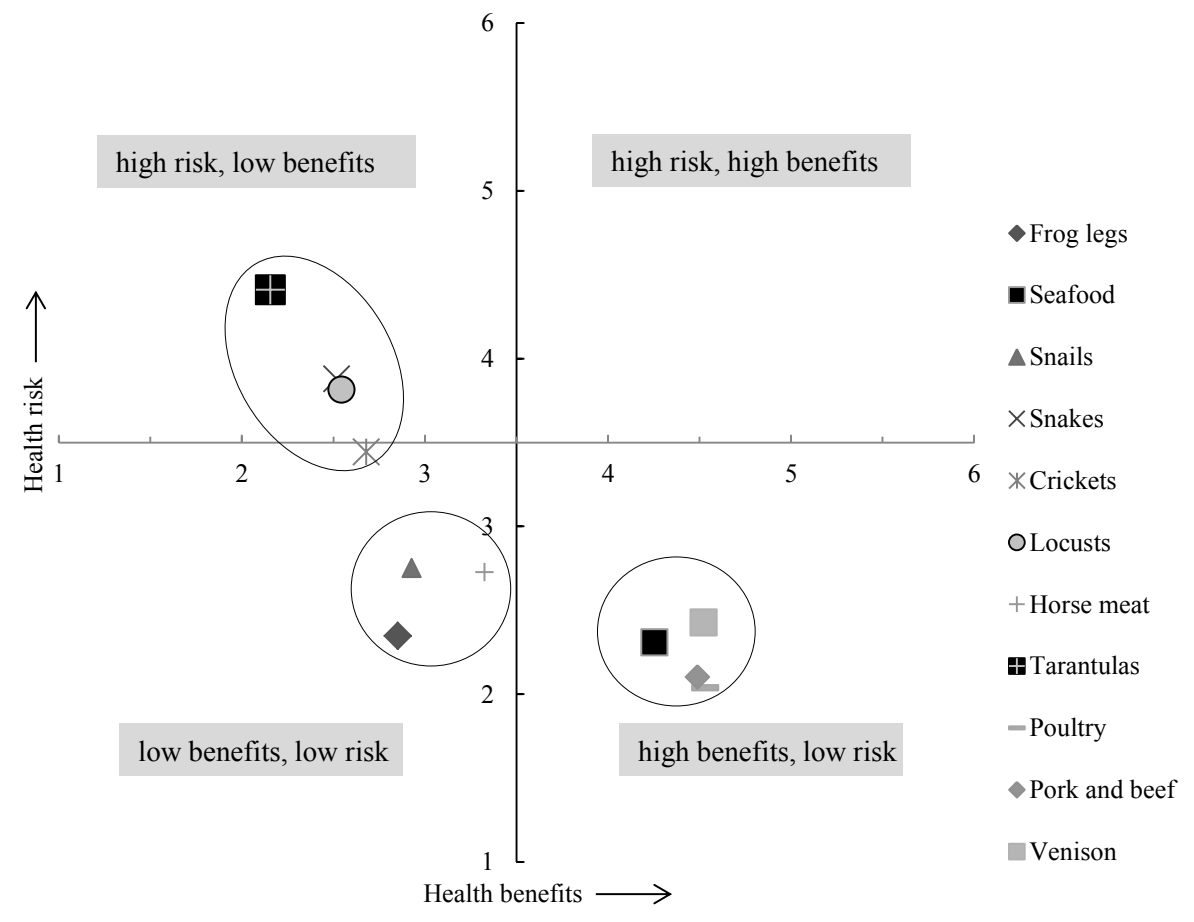

Figure 4. Two-dimensional chart of health benefits and risks associated with the consumption of selected products for all respondents

Rho Spearman's correlation values between the FNS scale parameters and health risk assessment resulting from consuming traditional and known as well as new, unknown and atypical products for Tri-City consumers were estimated and evaluated. Regarding edible insects (crickets and locusts), no statistically significant correlation was found, which means that the surveyed consumers with a high degree of neophobia did not perceive the risk associated with their consumption. The Speraman's coefficient values determined for crickets $(0.032)$ and poultry $(0.033)$ were at a similar level, which may be surprising on the one hand, and positively surprising on the other.

These results may indicate the openness of Tri-City consumers to new, unknown products. In the case of products known and often consumed in our culture, such as poultry, pork, beef, venison or even horse, and with which the Polish consumer is already "familiar", such as frogs' legs, seafood or snails, it has been found that greater benefits associated with their consumption were accompanied by lower levels of neophobia. The relationship between benefits and neophobia, related to the consumption of products unknown to Polish consumers (such as snakes, locusts, crickets or tarantula) was reversed. It was found that the perception of the significant benefits associated with their consumption was accompanied by a high level of neophobia. This result, however, is not surprising because if there are indications in the minds of consumers that these are safe products and their consumption is beneficial in terms of nutrition and health, then the lack of one's own experience arising from contact in everyday life with these products may cause to some extent a justified feeling of fear.

The perception of the abovementioned products as potential health risk factors associated with their consumption showed that gender significantly and statistically differentiated opinions in the cases of products such as: frogs' legs, seafood, snails, snakes and crickets $(\mathrm{p} \leq 0.05)$ and locust $(\mathrm{p} \leq 0.001)$. The age criterion differentiated the opinions of respondents about the most products, except seafood and horsemeat. In the case of frogs' legs, snails, snakes, crickets and tarantula, the significance of the effect of age as a feature differentiating the perception of risk associated with the consumption of these products was found to be $p \leq 0.05$, while in the case of locusts, poultry, beef and pork at $\mathrm{p} \leq 0.001$. 


\section{Health benefits vs. risk in familiar and unfamiliar products}

The evaluation also assessed how respondents qualified selected products of animal origin depending on the benefits and health risks associated with their inclusion in a diet. On the basis of average assessments of health benefits and risks resulting from the consumption of selected products, Figure 4 was prepared for all the respondents. The chart shows its quarters, which differ in terms of risk-benefit ratio. To the area corresponding to high risk and small benefits associated with consumption, the respondents qualified tarantulas, locusts, snakes and crickets that were already beyond the boundaries of division. Another focus within the low-risk and low-value area was on products such as snails, frogs' legs and horsemeat. The least risky and most profitable group included beef and pork, poultry and game, as well as seafood and seafood products. No product was assigned to the high-risk and high-value area.

\section{CONCLUSIONS}

The conducted study of consumers' attitudes of the Tri-City toward edible insects as food allowed to formulate the following conclusions:

The majority of seekers with a high degree of VARSEEK were men aged 21-40 with higher education. The degree of search for diversity in food significantly depended on factors such as gender, age and education. The avoiders group was represented in equal proportions by men and women aged 41 and above with vocational education.

Gender statistically and significantly differentiated the opinions of the respondents regarding health benefits conditioned by the consumption of various products only in the case of snakes and crickets. A statistically significant effect of age on the opinions of respondents regarding health benefits was shown, which was related to the consumption of: snakes, locusts, horse and tarantula. Whereas it was highly significant when it comes to consumption of: snails, crickets, poultry, beef and pork.

The results of FNS scale indicate that the dominant attitude toward food among the Tri-City residents was average (neutral). The age group of 21-40 years old was characterized by a low level of neophobia in comparison to other age groups. At the same time, this group was characterized by the lowest percentage of people with high levels of neophobia. Among the respondents with low levels of neophobia, the dominating group comprised of people with secondary and higher education. The group of women was characterized by a higher percentage of people with a low level of neophobia than men. At the same time, men dominated in the group of people with high levels of neophobia. Age and education were the factors that had a significant influence on the neophobia level, while gender did not have a significant influence.

Gender was the factor that differentiated opinions on health risks in products such as frogs' legs, seafood, snails, snakes, crickets and locusts. It was found that there was no correlation between the degree of food neophobia and the risk assessment resulting from the consumption of edible insects (locusts and crickets) by consumers.

The obtained results try to explain the issue of acceptance conditions of a new and rather controversial product, which are edible insects to the inhabitants of Europe. The lack of results of consumer research conducted in Poland on the acceptance of edible insects as food should be an incentive to undertake such research on a larger scale and in different regions of the country.

\section{REFERENCES}

1. Alamu O.T., Amao A.O., Nwokedi C.I., Oke O.A., Lawa I.O.: Diversity and nutritional status of edible insects in Nigeria: A review. Int. J. Biodiver. Conserv. 2013; 5(4): 215-222.

2. Asperin A.E., Phillips W.J., Wolfe K.: Exploring Food Neophobia and Perceptions of Ethnic Foods: The Case of Chinese and Thai Cuisines. International CHRIE Conference-Refereed Track. 2011; 4: 1-9.

3. Ayieko M.A., Kinyuru J.N., Ndong M.F., Kenji G.M.: Nutritional Value and Consumption of Black Ants (Carebara vidua Smith) from the Lake Victoria Region in Kenya. Adv. J. Food Sci. Technol. 2012; 4(1): 39-45.

4. Bartkowicz J.: Tri-City Consumer's Attitudes towards Eating Edible Insects as an Alternative Source of Food. Handel Wewnętrzny. 2017; 1(366): 156-166.

5. Back B., Wilde J.: Czerw pszczeli-niekonwencjonalne źródło białka zwierzęcego, Biuletyn Naukowy. 2002; 18: 229-237 (in Polish).

6. Biznes Raport.: Rynek mięsa w Polsce. Rynek mięsny w natarciu. Gazeta Finansowa, 2017; 28-31 (in Polish).

7. Caparros M.R., Sablon L., Geuens M., Brostaux Y., Alabi T., Blecker Ch., Drugmand D., Haubruge E., Francis F.: Edible Insects Acceptance by Belgian Consumers: Promising Attitude for Entomophagy Development. J. Sens. Stud. 2014; 29: 14-20.

8. Dodd T.H., Pinkleton B.E., Gustafson A.W.: External Information Sources of Product Enthusiasts: Differences between Variety Seekers, Variety Neutrals, and Variety Avoiders, Psychol. Mark. 1996; 13(3): 291-304.

9. Dreon A., Paoletti M.: The wild food (plants and insects) in Western Friuli local knowledge (FriuliVenezia Giulia, North Eastern Italy). Contributions to Natural History. 2009; 12(1): 461-488.

10. Fernández-Ruiz N., Claret A., Chaya C.: Testing a Spanish-version of the Food Neophobia Scale. Food Qual. Prefer.. 2012; 28: 222-225.

11. House $J .:$ Consumer acceptance of insect-based foods in the Netherlands: Academic and commercial implications, Appetite. 2016; 107: 47-58. 
12. Januszewska R., De Pelsmaeker S., Gellynck X., Dewettinck $K$.: Understanding variety-seekers and neopholics tasting traditional products. Fourth European Conference on Sensory and Consumer Research, A Sense of Quality (poster). 2010.

13. Jeżewska-Zychowicz M., Babicz-Zielińska E., Laskowski $W$.: Konsument na rynku nowej żywności. Wybrane uwarunkowania spożycia, Wydawnictwo SGGW, Warszawa. 2009 (in Polish).

14. Jeżewska-Zychowicz M. eds.: Nieznana żywność a postawy i zachowania konsumentów, Wydawnictwo SGGW, Warszawa. 2009 (in Polish).

15. Kish G.B., Donnenwerth G.V.: Interests and stimulus seeking. J. Couns. Psychol. 1969; 16(6): 551-556.

16. Kinyuru J.N., Konyole S.O., Roos N., Onyango Ch.A., Owino V.O., Owour B.O., Estambale B.B., Friis H., Aagaard-Hansen J., Kenji G.M.: Nutrient composition of four species of winged termites consumed in western Kenya. J. Food Compos. Anal. 2013; 30: 120-124.

17. Kowalczuk I.: Poziom i uwarunkowania neofobii żywieniowej polskich konsumentów. w JeżewskaZychowicz M. red.. Nieznana żywność a postawy i zachowania konsumentów. Warszawa, Wydawnictwo SGGW, 2009 (in Polish).

18. Lindeberg S.: Paleolithic diet ("stone age" diet). Scandinavian J. Nutr. 2005; 49(2): 75-77.

19. Melo V., Calvo C., Quirino T., Macin S., Muniz E.: Escamoles Ant Eggs Liometopum apiculatumm Source of Metal Ions for Human Health. J. Chem. and Chemical Engineering. 2013; 7: 556-559.

20. Mlcek J., Rop O., Borkovcova M., Bednarova M.: A Comprehensive Look at the Possibilities of Edible Insects as Food in Europe-A Review. Pol. J. Food and Nutr. Sci. 2014; 64(3): 147-157.

21. Muhammad R., Abdullah K.M., Zahari M.S.M., Shariff S.M.: Revealing the Scenario of Food Neophobia among Higher Learning Institution Students from Klang Valley, Malaysia. Procedia-Social and Beh. Sci. 2015; 170: 292-299.

22. Muhammad R., Ibrahim M.A., Ahmad R., Hanan F.: Psychological Factors on Food Neophobia among the Young Culinarian in Malaysia: Novel food preferences. Procedia-Social and Beh. Sci. 2016; 222: 358-366.

23. Niewczas M.: Kryteria wyboru żywności. Żywn. Nauka. Technol. Jakość., 2013; 6(91): 204-219 (in Polish).

24. Olabi A., Najm N.E., Baghdadi O. Morton J.: Food neophobia levels of Lebanese and American college students. Food Qual. Prefer. 2009; 20: 353-362.

25. Olsen J., Atkin T., Thach L., Cuellar S.: Exploring Attributes of Variety Seeking Wine Consumers in the US, AWBR 8th International Conference Geisenheim, Germany, 2014; 1-19.

26. Overstreet R.M.: Flavor Buds and Other Delights. J. Parasitol. 2003; 89(6): 1093-1107.

27. Pelchat M.L., Pliner P.: "Try it, you"ll like it". Effects on information on willingness to try novel foods. Appetite. 1995; 24: 153-165.
28. Portal Spożywczy. http://www.portalspozywczy. $\mathrm{pl} / \mathrm{mieso} /$ wiadomosci/wladze-prl-skuteczniewybily-polakom-z-glowy-tradycje-jedzeniadziczyzny,153412.html (Accessed 25.09.2019).

29. Pliner P., Hobden K.: Development of scale to measure the trait of food neophobia in humans. Appetite. 1992; 19(2): 105-120.

30. Pliner P., Salvy S.: Food neophobia in humans. In The Psychology of Food Choice. (Eds.) Shepherd R., Raats M. Frontiers in Nutr. Sci. 2006; 75-92.

31. Rozin P.: The selection of food by rats, humans and other animals. In Advances in the Study of Behavior, Rosenblatt J.S., Hinde R.A, Beer C, Busnel M. eds. New York, Academic Press, 1976; 6: 21-76.

32. Rozin P.: Cultural approaches to human food preferences. In Nutritional Modulation of Neural Function, Morley J.E., Sterman M.B., Walsh J.T. eds. New York, Academic Press, 1988: 137-153.

33. Rozin P., Fallon A.E.: A perspective on disgust. Psychol. Rev. 1987; 94(1); 23-41.

34. Shiv B., Fedorikhin A.: Heart and Mind in Conflict: the Interplay of Affect and Cognition in Consumer Decision Making. J. Consumer Res. 1999; 26(3): 278-292.

35. Siriamornpun $S$., Thammapat $P$.: Insects as a Delicacy and Nutritious Food in Thailand, In Using Science and Technology to Improve Nutrition National Development, Robertson \& Lupien eds. IUFoST. 2008; 1-12.

36. Stanisz A.: Przystępny kurs statystyki z zastosowaniem Statistica PL na przykładach z medycyny. T1. StatSoft Polska Sp. Z o.o., Kraków, 2007.

37. Tuorila H., Läteenemäki L., Pohjalainen L., Lotti L.: Food neophobia among the Finns and related responses to familiar and unfamiliar foods. Food Qual. Prefer. 2001; 12(1): 29-37.

38. UNEP.: The Enviromantal Food Crisis: The Environment's Role in Averting Food Crisis. Nellemann C., MacDevette M., Manders T., Eickhout B., Svihus B., Gerdien Prins A., Bjørn P., Kaltenborn B.P. eds. The environmental food crisis. The environment's role in averting future food crises a UNEP rapid response assessment. United Nations Environment Programme, GRID-Arendal. 2009, 104.

39. Van Huis A., Van Itterbeeck J., Klunder H., Mertens E., Halloran A., Muir G., Vantomme P.: Edible insects: Future prospects for food and feed security, FAO, Rome, Forestry Paper 171, 2013.

40. Van Trijp H.C.M., Steenkamp J.E.B.: Consumers'variety seeking tendency with respect to foods: Measurement and managerial implications. Eur. Rev. Agric. Econ., Oxford Journals. 1992; 19(2): 181-195.

Received: 02.12. 2019

Accepted: 02.03.2020 